\title{
Publisher Correction: The degree of prevalence of similarity between outer tropical cyclone rainbands and squall lines
}

\author{
Cheng-KuYu, Che-Yu Lin, Lin-Wen Cheng, Jhang-Shuo Luo, Chun-Chieh Wu \& Ying Chen
}

Correction to: Scientific Reports https://doi.org/10.1038/s41598-018-26553-8, published online 29 May 2018

The original HTML version of this Article omitted an affiliation for Chun-Chieh Wu and Ying Chen. The correct affiliation is listed below:

Department of Atmospheric Sciences, National Taiwan University, Taipei, Taiwan

This has now been corrected in the HTML version of this Article; the PDF was correct at the time of publication.

(c) (i) Open Access This article is licensed under a Creative Commons Attribution 4.0 International License, which permits use, sharing, adaptation, distribution and reproduction in any medium or format, as long as you give appropriate credit to the original author(s) and the source, provide a link to the Creative Commons license, and indicate if changes were made. The images or other third party material in this article are included in the article's Creative Commons license, unless indicated otherwise in a credit line to the material. If material is not included in the article's Creative Commons license and your intended use is not permitted by statutory regulation or exceeds the permitted use, you will need to obtain permission directly from the copyright holder. To view a copy of this license, visit http://creativecommons.org/licenses/by/4.0/.

(C) The Author(s) 2019 